\title{
Effect of zinc nutrition on yield of rice-wheat cropping system and soil properties
}

\author{
PEPAKAYALA VARALAKSHMI ${ }^{1}$, POLAGANI NAGARJUNA ${ }^{2}$, MOHAN BABU YN $^{3}$, \\ ADI LAKSHMI G ${ }^{4}$, ARADHNA KUMARI ${ }^{5}$ AND SANTOSH K SINGH ${ }^{6^{*}}$
}

\begin{abstract}
A study was conducted in anongoing experiment under AICRP on micronutrients at nursery jhilli of RPCAU, research farm. The experiment consisted of thirteen treatments, of which twelve combinations were of four doses of zinc (Zn) $\left(2.5,5.0,7.5\right.$ and $\left.10 \mathrm{~kg} \mathrm{ha}^{-1}\right)$, three frequencies (only once, alternate year and every year) of application along with control withthe no-zinc application. Rice and wheat crops were grown in succession with the recommended dosages of fertiliser viz. 120:60:40 of N: $\mathrm{P}_{2} \mathrm{O}_{5}: \mathrm{K}_{2} \mathrm{O}$ applied as Urea, DAP, and Potash, respectively. Surface soil samples (0-15 $\mathrm{cm}$ ) were collected after the harvest of the wheat crop in the year 2018, i.e. after completion of six years of the experiment, and analysed for soil physical and chemical properties. The availability of nitrogen, sulphur, organic carbon content and aggregate stability increased, and the bulk density, phosphorous availability decreased with increasing doses and zinc application rates. No effect on soil availability of potassium, pH and EC. The treatment $\mathrm{T}_{7}$ i.e., application of zinc @ $7.5 \mathrm{~kg} \mathrm{Zn} \mathrm{ha}{ }^{-1}$ in alternate year application was the best treatment with regards to yield of rice-wheat cropping $\left(982.9 \mathrm{q} \mathrm{ha}^{-1}\right)$ and also for good physical and chemical properties of the soil.
\end{abstract}

ARTICLE INFO

\begin{tabular}{lll}
\hline Received on & $:$ & $11 / 11 / 2020$ \\
Accepted on & $:$ & $14 / 02 / 2021$ \\
Published online & $:$ & $19 / 03 / 2021$ \\
\hline
\end{tabular}

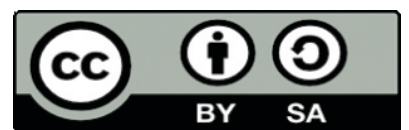

\section{KEYWORDS}

cropping system, dose, frequency, Rice-wheat, zinc

\section{INTRODUCTION}

$\mathrm{Z}$ inc is the most deficient micronutrient in the rice-wheat cropping system. Zinc remains as an important element in the human diet. So, zinc content in the plant should be increased. But the zinc use efficiency is significantly less in calcareous soils and ultimately reduces the availability to plants (Singh and Bhatt, 2013). The causes for the spurt in $\mathrm{Zn}$ deficiency in Asian countries include the introduction of high yielding varieties of rice and wheat, application of high rates of high analysis fertilisers such as urea and diammonium phosphate, removal of both grain and straw from the field at harvest, reduced to almost nil application of organic manures and development and adoption of two- to three- crops a year intensive crop rotations, such as rice-wheat (Prasad, 2010) resulting in the mining of native soil nutrients. So, at the very outset, it is essential to know about the factors that affect the availability of zinc. The distribution pattern of the $\mathrm{Zn}$ is highly determined by soil reaction $(\mathrm{pH})$, free calcium carbonate, organic carbon, and particle size fractions (Singh et al.,2013). Other nutrients may interact with $\mathrm{Zn}$ by affecting its availability from soils and its status in the plant through the processes of growth or $\mathrm{Zn}$ absorption, distribution or utilisation. In so doing, they may enhance or depress the

${ }^{1}$ Deptt. of Soil Science and Ag.Chemistry, PJTSAU, Hyderabad, Andhra Pradesh, India

${ }^{2}$ Deptt. of Agronomy, ANGRAU, Bapatla, Andhra Pradesh, India ${ }^{3}$ Deptt. of Agronomy, Kadiri Babu Rao College of Ag. and Horti., Kanigiri, Andhra Pradesh, India

${ }^{4}$ Department of Agronomy, ANGRAU, Tirupathi, Andhra Pradesh,India ${ }^{5}$ College of Agriculture, JNKVV, Ganj Basoda, Madhya Pradesh, India ${ }^{6}$ Department of Soil Science, RPCAU, Pusa, Samastipur, Bihar, India ${ }^{*}$ Corresponding author email : Santoshraupusa@gmail.com response of plant growth to $\mathrm{Zn}$. Conversely, Zn may affect other nutrients in the same ways. An interaction between two nutrients is considered statistically significant when the level of application of one nutrient affects plants' response to the other nutrient and vice-versa (Singh et al., 2013). When plants' response to one nutrient increases with an increase in the level of the other nutrient, the interaction is said to be positive, and the nutrients are said to be synergistic. On the other hand, when the response to one nutrient decreases with an increase in the other nutrient level, the interaction is said to be negative, and the two nutrients are said to be antagonistic. Zn also shows the synergistic and antagonistic effects on other nutrients it may affect the crop growth and yield. So it important to know about the effect of higher doses of zinc on other nutrient availability and physicochemical properties. Where interaction does occur, it is important for diagnosis and effective treatment of $Z n$ deficiency in crops.

\section{MATERIALS AND METHODS}

Field site and experimental design

A six-year long-term field experiment was initiated during Kharif 2012-13 with a rice-wheat cropping system under AICRP on micronutrients at the nursery jhilli area of Dr. Rajendra Prasad Central Agricultural University, Pusa, Bihar, India. The experimental site is situated at a latitude of 25094 ' $N$, a longitude of $85067^{\prime} \mathrm{E}$ and an altitude of 52.00 metres above MSL. The climate is humid subtropical with a hot-humid summer and winter too cold with an average annual rainfall of $1100 \mathrm{~mm}$. In this area, recurrent floods and droughts are normal. The soil belongs to the large group Calciorthent, textured sandy loam, reaction alkaline ( $\mathrm{pH}$ of 8.52$)$, organic 
carbon medium, nitrogen, phosphorus and potassium and sulphur and zinc deficient.The experiment was laid out in Randomized Block Design (RBD) with thirteen treatments $\left(\mathrm{T}_{1}-\mathrm{T}_{13}\right)$ and three replications. Treatments $\left(\mathrm{T}_{1}-\mathrm{T}_{4}\right)$ received zinc @ $2.5 \mathrm{~kg} \mathrm{ha}^{-1}, 5.0 \mathrm{~kg} \mathrm{ha}^{-1}, 7.5 \mathrm{~kg} \mathrm{ha}^{-1}$ and $10.0 \mathrm{~kg} \mathrm{ha}^{-1}$ zinc as $\mathrm{ZnSO}_{4}$ respectively, only once during Kharif. Treatments $\left(\mathrm{T}_{5}-\mathrm{T}_{8}\right)$ received same doses of zinc as treatments $\left(\mathrm{T}_{1}-\mathrm{T}_{4}\right)$, in alternate years in Kharif and treatments $\left(\mathrm{T}_{9}-\mathrm{T}_{12}\right)$ received same doses of zinc as treatments $\left(\mathrm{T}_{1}-\mathrm{T}_{4}\right)$, every year in Kharif. Treatment $\mathrm{T}_{13}$ was the control which did not receive any dose of zinc externally. Rice and wheat crops were grown in succession with recommended doses of fertiliser viz. 120:60:40 of $\mathrm{N}$ : $\mathrm{P}_{2} \mathrm{O}_{5}: \mathrm{K}_{2} \mathrm{O}$ applied as Urea, DAP and Potash, respectively.

At the end of the experiment, soil samples were collected after the wheat harvest in 2018. In order to evaluate the grain and straw Zn uptake, the plant samples were also obtained. Grain and straw yields of wheat for each plot were recorded at harvest. A di-acid [nitric acid (HNO3): perchloric acid (HClO4); a 9:4 ratio] digest on an atomic absorption spectrophotometer was examined for zinc in grain and straw samples (Tandon, 2005) and presented in Table 1. The collected soil samples were analysed in the laboratory to examine the $\mathrm{N}, \mathrm{P}, \mathrm{K}, \mathrm{pH}, \mathrm{EC}, \mathrm{OC}$ and aggregate stability with different doses and frequencies of zinc application in calcareous soil.

\section{Collection of soil sample}

Soil samples were collected from $0-15 \mathrm{~cm}$ depth in all treated plots of the experimental field. The collected samples were air-dried in the shade at room temperature, ground with the help of wooden slab and roller then passed through a $2 \mathrm{~mm}$ sieve and kept in polythene bags with proper labeling for analysis. Standard methods were followed for analysis of physico-chemical properties of the soil are presented below.

\section{Study of physical properties of soil \\ Soil texture}

It was determined by international pipette method as described by Piper (1966).

\section{Bulk density}

The core sampler was pressed into the soil in such a way that soil is collected by the core. Soil samples were dried in the oven at $105^{\circ} \mathrm{c}$ for 24 hours. Bulk density $\mathrm{Mg} \mathrm{m}^{-3}$ was calculated by dividing the weight of the dried soil by the volume of core (Blake and Hartage, 1986) using the following formula.

Bulk density $\left(\mathrm{Mg} \mathrm{m}^{-3}\right)=\frac{\text { Weight of oven-dry soil }(\mathrm{Mg})}{\text { Volume of soil }\left(\mathrm{m}^{3}\right)}$

The volume of the soil was taken as the inner volume of the core sampler, which was in turn calculated by $\Pi r^{2} \mathrm{~h}$ ( $\mathrm{r}=$ radius, h- the height of the core).

\section{Gravimetric water content}

In this method, a fresh soil is dried in an oven, and the loss of water on drying is determined. Drying of soils is done in an oven at $105^{\circ} \mathrm{C}$ up to a constant weight, and per cent is calculated using the formula:
$\%$ Moisture Weight of fresh soil - Weight of dry soil $\times 100$ content

Weight of dry soil

\section{Aggregate stability}

Large clods were broken by hand into smaller pieces along natural cleavage having a size greater than $8 \mathrm{~mm}$. The aggregates were separated using the dry sieving technique (Chepli, 1962). After dry sieving, the soil from each sieve was weighed separately in analytical balance. Then by using this data, mean weight diameter and geometric mean weight diameter were calculated by using the following formulas.

$$
\mathrm{MWD}=\Sigma W \mathrm{~W} \text { i }
$$

Where,

Xi: Arithmetic mean diameter of each size fraction ( $\mathrm{mm}$ )

Wi: Proportion of the total sample weight occurring in the fraction i

Where,

$$
\text { GMD=exp } \Sigma w i \log x i / \Sigma w i
$$

Wi is the weight of aggregate in a size class of average diameter $\mathrm{Xi}$

$\Sigma$ Wi is the total weight of the sample

\section{Study of chemical properties of soil}

Soil chemical properties viz. Soil pH [(Jackson, 1973)], Electrical conductivity (EC) [(Bower and Wilcox, 1965)], Organic carbon [Walkley and Black (1934)], Available nitrogen (Mineralisable nitrogen) [Subbiah and Asiji (1956)], Available phosphorus [Olsen's method (1954)], Available potassium [(Champman and Pratt, 1961)], and Available sulphur [(Chesnin and Yien, 1950)] were determined as per the procedure cited against each chemical parameter.

\section{RESULTS AND DISCUSSION}

\section{The cumulative yield of rice-wheat system}

The cumulative total yield over six years (Rice + Wheat) was recorded significantly higher with every year application of $7.5 \mathrm{~kg} \mathrm{Zn} \mathrm{ha}^{-1}\left(\mathrm{~T}_{11}\right)\left(1026 \mathrm{q} \mathrm{ha}^{-1}\right)$ (Table 1). It was at par with every year application of $5 \mathrm{~kg} \mathrm{Zn}^{-1}\left(\mathrm{~T}_{10}\right)\left(1016.1 \mathrm{q} \mathrm{ha}^{-1}\right), 10 \mathrm{~kg} \mathrm{Zn}$ $\mathrm{ha}^{-1}\left(\mathrm{~T}_{12}\right)\left(981.7 \mathrm{qha}^{-1}\right)$ and $7.5 \mathrm{~kg} \mathrm{Zn} \mathrm{ha}^{-1}\left(\mathrm{~T}_{7}\right)\left(982.9 \mathrm{q} \mathrm{ha}^{-1}\right), 10 \mathrm{~kg}$ $\mathrm{Zn} \mathrm{ha}{ }^{-1}\left(\mathrm{~T}_{8}\right)\left(1009.5 \mathrm{q} \mathrm{ha}^{-1}\right)$ at alternate years (Table 1). Effect of different doses and frequencies of zinc on macronutrients content were analysed in post-harvest soil after completion of the six years experiment. Zinc application as individual doses and yield of the wheat for the sixth year (2018) was not significantly correlated with the available macronutrients and organic carbon content. If we consider the cumulative amount of applied zinc and cumulative biological yields of both rice and wheat, over six years showed a positive correlation with most of the nutrient availability. This may due to applied zinc increases the crop growth, which ultimately adds the more organic matter to the soil through root biomass. Mineralisation of this organic matter increases the available nutrient content in the soil. Along with the addition of nutrients, it also changes some physical properties of the soil. This yield was correlated with organic matter addition. These findings are in tune with observations by Keram et al.(2012), 
based on a pooled analysis of data he revealed that yield, harvest index, nutrient (N, K and $\mathrm{Zn}$ ) uptake and quality increased significantly with the application of recommended NPK+Zn@ $20 \mathrm{~kg} \mathrm{ha}^{-1}$ by wheat as compared to NPK alone. In general, yield, harvest index, total nutrient uptake and quality increased up to the highest level of zinc, except total P uptake (Keram et al., 2012).

Table 1: Effect of different doses and frequencies of zinc on cumulative yield $\left(\mathrm{q} \mathrm{ha}^{-1}\right)$ of rice and wheat crops over six years

\begin{tabular}{|c|c|c|c|c|}
\hline Treatment & $\begin{array}{c}\text { Cumulative } \\
\text { Zn content } \\
\text { (kg ha } 1 \text { ) }\end{array}$ & $\begin{array}{c}\text { RICE } \\
\text { (grain + } \\
\text { straw) }\end{array}$ & $\begin{array}{c}\text { WHEAT } \\
\text { (grain + } \\
\text { straw) }\end{array}$ & $\begin{array}{c}\text { TOTAL } \\
\text { (Rice + } \\
\text { Wheat) }\end{array}$ \\
\hline $\begin{array}{l}\mathrm{T} 1 \text { ( } 2.5 \mathrm{~kg} \mathrm{Zn} \mathrm{ha-1} \text { during } \\
\text { first year) }\end{array}$ & 2.5 & 442.8 & 387.3 & 830.1 \\
\hline $\begin{array}{l}\mathrm{T} 2(5.0 \mathrm{~kg} \mathrm{Zn} \mathrm{ha-1} \text { during } \\
\text { first year) }\end{array}$ & 5.0 & 477.8 & 407.6 & 885.4 \\
\hline $\begin{array}{l}\mathrm{T} 3 \text { (7.5 kg Zn ha-1 during } \\
\text { first year) }\end{array}$ & 7.5 & 513.7 & 415.5 & 929.2 \\
\hline $\begin{array}{l}\mathrm{T} 4\left(10.0 \mathrm{Zn} \mathrm{kg} \mathrm{ha-1}{ }^{-1} \text { uring }\right. \\
\text { first year) }\end{array}$ & 10.0 & 515.0 & 421.6 & 936.6 \\
\hline $\begin{array}{l}\mathrm{T} 5\left(2.5 \mathrm{~kg} \mathrm{Zn} \mathrm{ha}^{-1} \text { at }\right. \\
\text { alternate years })\end{array}$ & 7.5 & 486.1 & 400.2 & 886.3 \\
\hline $\begin{array}{l}\mathrm{T} 6\left(5.0 \mathrm{~kg} \mathrm{Zn} \mathrm{ha}^{-1} \text { at }\right. \\
\text { alternate years) }\end{array}$ & 15.0 & 499.5 & 429.3 & 928.8 \\
\hline $\begin{array}{l}\mathrm{T} 7\left(7.5 \mathrm{~kg} \mathrm{Zn} \mathrm{ha}^{-1} \mathrm{at}\right. \\
\text { alternate years })\end{array}$ & 22.5 & 510.5 & 472.4 & 982.9 \\
\hline $\begin{array}{l}\mathrm{T} 8\left(10.0 \mathrm{~kg} \mathrm{Zn} \mathrm{ha}^{-1} \text { at }\right. \\
\text { alternate years })\end{array}$ & 30.0 & 521.8 & 480.7 & 1009.5 \\
\hline $\begin{array}{l}\mathrm{T} 9(2.5 \mathrm{~kg} Z \mathrm{Zn} \text { ha-1every } \\
\text { year })\end{array}$ & 12.5 & 491.8 & 428.5 & 920.3 \\
\hline $\begin{array}{l}\mathrm{T} 10(5.0 \mathrm{~kg} \mathrm{Zn} \mathrm{ha-1} \text { every } \\
\text { year) }\end{array}$ & 30.0 & 528.0 & 486.6 & 1016.1 \\
\hline $\begin{array}{l}\mathrm{T} 11(7.5 \mathrm{~kg} \mathrm{Zn} \mathrm{ha-1} \text { every } \\
\text { year) }\end{array}$ & 45.0 & 530.1 & 497.1 & 1026.1 \\
\hline $\begin{array}{l}\mathrm{T} 12(10.0 \mathrm{~kg} \text { Zn ha-1every } \\
\text { year) }\end{array}$ & 60.0 & 517.0 & 469.7 & 981.7 \\
\hline T13 (Control) & - & 415.3 & 380.3 & 795.6 \\
\hline SE.m \pm & & 13.3 & 11.6 & 24.8 \\
\hline $\mathrm{CD}(\mathrm{p}=0.05)$ & - & 38.7 & 33.7 & 72.4 \\
\hline
\end{tabular}

Chemical properties of soil

Organic carbon, Nitrogen, Phosphorous, Potassium and Sulphur content

Organic carbon content was directly related to organic matter addition. It ranged from 0.37 to 0.45 per cent. Organic carbon content was higher in $\mathrm{T}_{8}, \mathrm{~T}_{10}$ and $\mathrm{T}_{11}$ treatments $(0.45 \%)$ as compared to all other treatments (Table 2). Nitrogen content varies from $256.67 \mathrm{~kg} \mathrm{ha}{ }^{-1}$ in control $\left(\mathrm{T}_{13}\right)$ to $299.8 \mathrm{~kg} \mathrm{ha}^{-1}$ in $\mathrm{T}_{11}$ treatment and $\mathrm{K}_{2} \mathrm{O}$ from 115 to $126 \mathrm{~kg} \mathrm{ha}^{-1}\left(\mathrm{~T}_{11}\right)$, S from $13.1 \mathrm{in}$ control to $15.6 \mathrm{~kg} \mathrm{ha}^{-1}\left(\mathrm{~T}_{12}\right)$ and $\mathrm{P}_{2} \mathrm{O}_{5}$ from $39.0\left(\mathrm{~T}_{12}\right)$ to $49.4 \mathrm{~kg} \mathrm{ha}$ ${ }^{1}$ (control). Treatment with Every year application of $7.5 \mathrm{~kg} Z \mathrm{Zn}$ ha $^{-1}\left(\mathrm{~T}_{11}\right)$ was shown the significantly higher amount of nitrogen (299.8 $\mathrm{kg} \mathrm{ha}^{-1}$ ) (Table 2) and was at par with every application of 5 and $10 \mathrm{~kg} \mathrm{Zn} \mathrm{ha}^{-1}$ (291.3 and $289.0 \mathrm{~kg} \mathrm{ha}^{-1}$ ), 7.5 $\left(282.0 \mathrm{~kg} \mathrm{ha}^{-1}\right)$ and $10 \mathrm{~kg} \mathrm{Zn} \mathrm{ha}^{-1}\left(282.0 \mathrm{~kg} \mathrm{ha}^{-1}\right)$ at alternate year. The sulphur content was significantly higher $\left(15.6 \mathrm{~kg} \mathrm{ha}^{-1}\right)$ in the plot treated with $5 \mathrm{~kg} \mathrm{Zn} \mathrm{ha}{ }^{-1}$ at every year $\left(T_{10}\right)$, and it was at par with every year application of $7.5,10 \mathrm{~kg} \mathrm{Zn} \mathrm{ha}^{-1}$ and with alternate year application of $10 \mathrm{~kg} \mathrm{Zn} \mathrm{ha}^{-1}$. A significant effect was not found in case of potassium availability. With the increase in organic matter by one-unit, total $\mathrm{N}$, available $\mathrm{P}_{2} \mathrm{O}_{5}$ and extractable $\mathrm{K}_{2} \mathrm{O}$ increases by $0.038,31.19$ and 5.92 units, respectively, as reported by (Dinesh Khadka, 2016).

Table 2: Effect of different doses and frequencies of zinc on available $\mathrm{N}, \mathrm{P}_{2} \mathrm{O}_{5}, \mathrm{~K}_{2} \mathrm{O}$ and $\mathrm{S}$ in post-harvest soil

\begin{tabular}{|c|c|c|c|c|}
\hline Treatment & $\begin{array}{c}\mathrm{N} \\
\left(\mathrm{kg} \mathrm{ha}^{-1}\right)\end{array}$ & $\begin{array}{c}\mathrm{P}_{2} \mathrm{O}_{5} \\
\left(\mathrm{~kg} \mathrm{ha}^{-1}\right)\end{array}$ & $\begin{array}{c}\mathrm{K}_{2} \mathrm{O} \\
\left(\mathrm{kg} \mathrm{ha}^{-1}\right)\end{array}$ & $\begin{array}{c}\mathrm{S} \\
(\mathrm{ppm})\end{array}$ \\
\hline $\begin{array}{l}\mathrm{T} 1(2.5 \mathrm{~kg} \mathrm{Zn} \mathrm{ha-1} \text { during } \\
\text { first year) }\end{array}$ & 261.3 & 48.1 & 114.3 & 13.5 \\
\hline $\begin{array}{l}\mathrm{T} 2\left(5.0 \mathrm{~kg} \mathrm{Zn} \mathrm{ha}^{-1} \text { during }\right. \\
\text { first year) }\end{array}$ & 274.0 & 48.0 & 117.3 & 13.6 \\
\hline $\begin{array}{l}\mathrm{T} 3(7.5 \mathrm{~kg} \mathrm{Zn} \mathrm{ha-1} \text { during } \\
\text { first year) }\end{array}$ & 282.0 & 47.3 & 118.2 & 14.2 \\
\hline $\begin{array}{l}\mathrm{T} 4 \text { (10.0 Zn kg ha-1 during } \\
\text { first year) }\end{array}$ & 284.0 & 47.9 & 119.5 & 14.3 \\
\hline $\begin{array}{l}\mathrm{T} 5\left(2.5 \mathrm{~kg} \mathrm{Zn} \mathrm{ha}^{-1} \text { at alternate }\right. \\
\text { year) }\end{array}$ & 275.0 & 47.3 & 117.0 & 13.9 \\
\hline $\begin{array}{l}\mathrm{T} 6\left(5.0 \mathrm{~kg} \mathrm{Zn} \mathrm{ha}^{-1} \text { at alternate }\right. \\
\text { year) }\end{array}$ & 276.0 & 46.6 & 120.7 & 14.3 \\
\hline $\begin{array}{l}\mathrm{T} 7\left(7.5 \mathrm{~kg} \mathrm{Zn} \mathrm{ha}^{-1} \text { at alternate }\right. \\
\text { year) }\end{array}$ & 282.0 & 46.3 & 122.0 & 14.3 \\
\hline $\begin{array}{l}\mathrm{T} 8\left(10.0 \mathrm{~kg} \mathrm{Zn} \mathrm{ha}^{-1} \text { at alternate }\right. \\
\text { year) }\end{array}$ & 286.0 & 44.0 & 121.3 & 14.9 \\
\hline T9 (2.5 kg Zn ha-1 every year) & 277.0 & 46.6 & 121.1 & 14.2 \\
\hline T10 (5.0 kg Zn ha-1 every year) & 291.3 & 41.3 & 125.7 & 15.4 \\
\hline T11 (7.5 kg Zn ha-1 every year) & 299.8 & 41.1 & 126.0 & 14.9 \\
\hline T12 (10.0 kg Zn ha-1 every year) & 289.0 & 39.0 & 124.0 & 14.5 \\
\hline T13 (Control) & 256.7 & 48.0 & 115.0 & 13.1 \\
\hline SE.m \pm & 7.51 & 0.778 & 2.09 & 0.43 \\
\hline $\mathrm{CD}(\mathrm{p}=0.05)$ & 21.9 & 2.3 & NS & 1.3 \\
\hline
\end{tabular}

In case of availability of phosphorous significantly lower amount was observed in $\mathrm{T}_{12}$ treatment $\left(39.0 \mathrm{~kg} \mathrm{ha}^{-1}\right)$ which was at par with $\mathrm{T}_{11}\left(41.1 \mathrm{~kg} \mathrm{ha}^{-1}\right)$ and $\mathrm{T}_{10}\left(41.3 \mathrm{~kg} \mathrm{ha}^{-1}\right)$ treatments. It ranged from 39.0 to $48.1 \mathrm{~kg} \mathrm{P}_{2} \mathrm{O}_{5} \mathrm{ha}^{-1}$. Lowest amount was obtained in $\mathrm{T}_{12}$ treatment $\left(39.0 \mathrm{~kg} \mathrm{ha} \mathrm{h}^{-1}\right)$. Phosphorous is antagonistic to the supply of zinc when it produces zincphosphate. The antagonistic impact often of the higher amount needed (macro) nutrient on the smaller amount required (micro) nutrient. So the supply of phosphate did not affect much by applying zinc. However, under conditions of high $\mathrm{Zn}$ supply, P may immobilise $\mathrm{Zn}$ in roots through the formation of $\mathrm{Zn}$ phytate and zinc phosphate, which has been shown to occur in a wide range of crop plants. Zinc deficiency leads to P accumulation in plants (Welch and Norvell, 1993), because $\mathrm{Zn}$ deficient plants lose control over P absorption mechanism. High doses of zinc can decrease plant absorption of $\mathrm{P}$ so that it accumulates in the soil. But the phosphorous is again immobilised by calcium carbonate $\backslash$ and form the insoluble calcium zincate. Mineralisation of phosphorous and 
sulfur from organic matter is also an important source of these nutrients. But the mineralised phosphorous is again immobilised by calcium carbonate $\backslash$ and form the insoluble calcium zincate. As discussed earlier, organic matter helps to hold on to positively charged potassium $\left(\mathrm{K}^{+}\right)$, calcium $\left(\mathrm{Ca}^{++}\right)$, and magnesium $\left(\mathrm{Mg}^{++}\right)$ions (Sustainable Agriculture Research \& Education, 2012) and increase their availability.

\section{$\mathrm{pH}$ and $\mathrm{EC}$}

The $\mathrm{pH}$ value of the experimental plot was ranged from 8.28 to 8.42 (Table 3). Soil pH did not vary significantly with the application of different loads (doses and frequency) of zinc. The electrical conductivity of the given experimental plots ranged from $0.26-0.31 \mathrm{dSm}^{-1}$ (Table 3). It was also not affected by the rate of zinc application. The experimental plot was very calcareous in nature, and the application of zinc was not affecting the $\mathrm{pH}$ and electrical conductivity (EC) of the soil. Similar results have been reported by Keram et al., 2012. But

Table 3: Effect of different doses and frequencies of zinc on O.C, pH, EC, bulk density and moisture content

\begin{tabular}{|c|c|c|c|c|c|}
\hline Treatment & OC (\%) & $\mathrm{pH}$ & 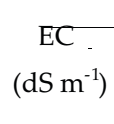 & $\begin{array}{c}\text { Bulk } \\
\text { density } \\
\left(\mathrm{g} \mathrm{cm}^{-3}\right)\end{array}$ & $\begin{array}{c}\text { Moisture } \\
\text { content } \\
(\%)\end{array}$ \\
\hline $\begin{array}{l}\mathrm{T} 1 \text { (2.5 kg Zn ha-1 } \\
\text { during first year) }\end{array}$ & 0.39 & 8.31 & 0.27 & 1.34 & 8.60 \\
\hline $\begin{array}{l}\mathrm{T} 2 \text { (5.0 kg Zn ha-1 } \\
\text { during first year) }\end{array}$ & 0.42 & 8.42 & 0.26 & 1.34 & 8.08 \\
\hline $\begin{array}{l}\mathrm{T} 3 \text { (7.5 kg Zn ha-1 } \\
\text { during first year) }\end{array}$ & 0.43 & 8.31 & 0.28 & 1.30 & 8.84 \\
\hline $\begin{array}{l}\mathrm{T} 4 \text { (10.0 Zn kg ha-1 } \\
\text { during first year) }\end{array}$ & 0.43 & 8.37 & 0.29 & 1.30 & 8.80 \\
\hline $\begin{array}{l}\mathrm{T} 5(2.5 \mathrm{~kg} \mathrm{Zn} \mathrm{ha-1} \\
\text { at alternate years) }\end{array}$ & 0.42 & 8.42 & 0.27 & 1.33 & 8.61 \\
\hline $\begin{array}{l}\mathrm{T} 6\left(5.0 \mathrm{~kg} \mathrm{Zn} \mathrm{ha}{ }^{-1}\right. \\
\text { at alternate years) }\end{array}$ & 0.43 & 8.35 & 0.28 & 1.30 & 8.70 \\
\hline $\begin{array}{l}\mathrm{T} 7(7.5 \mathrm{~kg} \mathrm{Zn} \mathrm{ha-1} \\
\text { at alternate years) }\end{array}$ & 0.44 & 8.37 & 0.28 & 1.28 & 9.00 \\
\hline $\begin{array}{l}\mathrm{T} 8\left(10.0 \mathrm{~kg} \mathrm{Zn} \mathrm{ha}{ }^{-1}\right. \\
\text { at alternate years) }\end{array}$ & 0.45 & 8.28 & 0.29 & 1.27 & 9.08 \\
\hline $\begin{array}{l}\text { T9 (2.5 kg Zn ha-1 } \\
\text { every year) }\end{array}$ & 0.42 & 8.31 & 0.27 & 1.33 & 8.70 \\
\hline $\begin{array}{l}\mathrm{T} 10(5.0 \mathrm{~kg} \mathrm{Zn} \mathrm{ha-1} \\
\text { every year) }\end{array}$ & 0.45 & 8.32 & 0.29 & 1.25 & 9.10 \\
\hline $\begin{array}{l}\text { T11 (7.5 kg Zn ha-1 } \\
\text { every year) }\end{array}$ & 0.45 & 8.28 & 0.29 & 1.23 & 9.13 \\
\hline $\begin{array}{l}\text { T12 (10.0 kg Zn ha } \\
\text { every year) }\end{array}$ & 0.44 & 8.28 & 0.31 & 1.29 & 8.90 \\
\hline T13 (Control) & 0.37 & 8.34 & 0.28 & 1.35 & 8.51 \\
\hline SE.m \pm & 0.011 & 0.22 & 0.010 & 0.022 & 0.150 \\
\hline $\mathrm{CD}(\mathrm{p}=0.05)$ & 0.03 & NS & NS & 0.07 & 0.44 \\
\hline
\end{tabular}

here, the high calcium carbonate (35\%) content of the experimental field acts as a buffering agent to resist the change in $\mathrm{pH}$.

\section{Physical properties of soil}

\section{Bulk density, Moisture Content and Aggregate Satbility}

Bulk density was significantly influenced by different zinc loads. It varied from 1.23 in treatment $T_{11}$ to $1.35 \mathrm{~g} \mathrm{~cm}^{-3}$ in treatment $\mathrm{T}_{13}$ (Table 3). Treatments $\mathrm{T}_{7}, \mathrm{~T}_{8}, \mathrm{~T}_{10}, \mathrm{~T}_{11}$ and $\mathrm{T}_{12}$ had significantly lower bulk density than control $\left(\mathrm{T}_{13}\right)$. Considerably low bulk density was observed in $7.5 \mathrm{~kg} \mathrm{Zn} \mathrm{ha}^{-1}$ at every year $\left(1.23 \mathrm{~g} \mathrm{~cm}^{-3}\right)$ treated plot where higher organic carbon was found. Table 3 showed that there was a significant difference in moisture content with different applications of zinc, and it varied from 9.13 to 8.51 per cent. Zinc treated plot with $7.5 \mathrm{~kg} \mathrm{ha}^{-1}$ at every year $\left(\mathrm{T}_{11}\right)$ recorded the highest moisture content $(9.13 \%)$, and it was at par with $\mathrm{T}_{7}, \mathrm{~T}_{8}$, $\mathrm{T}_{10}$ and $\mathrm{T}_{12}$ and lowest moisture content was recorded in control (8.51\%). Treatments $\mathrm{T}_{7}, \mathrm{~T}_{8}, \mathrm{~T}_{10}, \mathrm{~T}_{11}$ and $\mathrm{T}_{12}$ also registered significantly higher moisture content over control (Table 3).

Mean weight diameter (MWD) ranges from 2.95-3.57 mm. Higher MWD was recorded in every year treated plot with 7.5 $\mathrm{kg} \mathrm{Zn} \mathrm{ha}{ }^{-1}(3.57 \mathrm{~mm})$, and it was at par with $\mathrm{T}_{7}, \mathrm{~T}_{8}, \mathrm{~T}_{10}$ and $\mathrm{T}_{12}$. Geometric mean diameter (GMD) varied from 1.36 to 1.63 $\mathrm{mm}$. As MWD, every year treated plot with $7.5 \mathrm{~kg} \mathrm{Zn} \mathrm{ha}^{-1}$ was recorded higher $(1.63 \mathrm{~mm}) \mathrm{GMD}$, and it was at par with $\mathrm{T}_{7}, \mathrm{~T}_{8}$, $\mathrm{T}_{10}$ and $\mathrm{T}_{12}$ (Table 4). Increased rate of zinc application leads to an increase in both crop growth and yield. This ultimately leads to the increased organic matter addition through root decomposition, which adds organic carbon to the soil. It leads to the development of the soil's good physical condition, which ultimately increases the nutrient availability in the soil. The addition of different loads (doses and frequencies) of zinc was showed a significant effect on physical properties (bulk density, moisture content and aggregate stability) of soil. As we said earlier, the applied zinc increases the crop growth, which ultimately adds the more organic matter to the soil

Table 4: Effect of different doses and frequencies of zinc on aggregate stability

\begin{tabular}{|c|c|c|}
\hline Treatment & GMD (mm) & $\operatorname{MWD}(\mathrm{mm})$ \\
\hline $\mathrm{T}_{1}$ (2.5 kg Zn ha ${ }^{-1}$ during first year) & 1.43 & 3.06 \\
\hline $\mathrm{T}_{2}$ (5.0 kg Zn ha-1 during first year) & 1.49 & 3.12 \\
\hline $\mathrm{T}_{3}\left(7.5 \mathrm{~kg} \mathrm{Zn} \mathrm{ha}{ }^{-1}\right.$ during first year) & 1.54 & 3.18 \\
\hline $\mathrm{T}_{4}$ (10.0 Zn kg ha-1 during first year) & 1.58 & 3.24 \\
\hline $\mathrm{T}_{5}$ (2.5 kg Zn ha-1 at alternate years) & 1.54 & 3.21 \\
\hline $\mathrm{T}_{6}$ (5.0 kg Zn ha ${ }^{-1}$ at alternate years) & 1.58 & 3.34 \\
\hline $\mathrm{T}_{7}\left(7.5 \mathrm{~kg} \mathrm{Zn} \mathrm{ha}^{-1}\right.$ at alternate years $)$ & 1.61 & 3.43 \\
\hline $\mathrm{T}_{8}$ (10.0 $\mathrm{kg} \mathrm{Zn} \mathrm{ha}^{-1}$ at alternate years) & 1.62 & 3.47 \\
\hline $\mathrm{T}_{9}$ (2.5 kg Zn ha-1 every year) & 1.54 & 3.39 \\
\hline $\mathrm{T}_{10}$ (5.0 kg Zn ha-1 every year) & 1.59 & 3.52 \\
\hline $\mathrm{T}_{11}$ (7.5 kg Zn ha-1 every year) & 1.63 & 3.57 \\
\hline $\mathrm{T}_{12}\left(10.0 \mathrm{~kg} \mathrm{Zn} \mathrm{ha}^{-1}\right.$ every year) & 1.61 & 3.53 \\
\hline $\mathrm{T}_{13}$ (Control) & 1.36 & 2.95 \\
\hline$\overline{\text { SE.m } \pm}$ & 0.03 & 0.06 \\
\hline $\mathrm{CD}(5 \%)$ & 0.08 & 0.17 \\
\hline
\end{tabular}


through root biomass, which leads to a decrease in bulk density, increases in moisture-holding capacity, and stable formation aggregates.

\section{Correlation between cumulative zinc content with physical and chemical properties of soil}

The relationship between cumulative zinc content (total for 6 years) and physico-chemical properties of soil in rice wheat cropping system in calcareous soils has been presented in Table 5. Cumulative zinc content was positively and significantly correlated with Organic carbon (OC) $(\mathrm{r}=$ $\left.0.695^{* *}\right), \operatorname{MWD}\left(\mathrm{r}=0.862^{* *}\right), \operatorname{GMD}\left(\mathrm{r}=0.718^{* *}\right)$, moisture content $\left(0.662^{*}\right), \mathrm{N}\left(\mathrm{r}=0.742^{* *}\right), \mathrm{S}\left(\mathrm{r}=0.688^{* *}\right)$ and cumulative yield of rice-wheat cropping system $\left(0.786^{* *}\right)$. Electric conductivity and $\mathrm{K}_{2} \mathrm{O}$ in soil did not have any correlation with applied zinc ( $r=0.552$ NS and $0.796 \mathrm{NS}$ ) and had a negative correlation with $\mathrm{pH}\left(\mathrm{r}=-0.585^{*}\right)$, B.D $\left(\mathrm{r}=-744^{* *}\right)$ and available $\mathrm{P}_{2} \mathrm{O}_{5}\left(\mathrm{r}=-0.970^{* *}\right)$. Organic carbon (O.C) had significant positive correlation with $\operatorname{MWD}\left(\mathrm{r}=0.886^{* *}\right), \operatorname{GMD}\left(\mathrm{r}=0.968^{* *}\right)$, moisture content $\left(0.670^{*}\right)$ and with available $\mathrm{N}\left(\mathrm{r}=0.896^{* *}\right)$, $\mathrm{K}_{2} \mathrm{O}\left(\mathrm{r}=0.773^{* *}\right), \mathrm{S}\left(\mathrm{r}=0.884^{* *}\right)$. It was negatively correlated with B.D $\left(\mathrm{r}=-0.848^{* *}\right)$ and $\mathrm{P}_{2} \mathrm{O}_{5}\left(\mathrm{r}=-0.685^{* *}\right)$. No correlation was observed regarding $\mathrm{pH}$ and electrical conductivity of the soil. The result revealed that soil organic matter was significantly and positively correlated with primary nutrients namely; total $\mathrm{N}\left(\mathrm{r}=.73^{* *}\right)$ ), available $\mathrm{P}_{2} \mathrm{O}_{5}\left(\mathrm{r}=.57^{* *}\right)$ and extractable $\mathrm{K}_{2} \mathrm{O} \quad\left(\mathrm{r}=.35^{* *}\right)$. A significant and positive correlation was obtained for sulphur by Singh and Mishra (2012), Acquaye and Beringer (1989). The above observations show the indirect effect of zinc application on increased nutrient availability except for $\mathrm{P}_{2} \mathrm{O}_{5}$.

Table 5: Correlation between cumulative zinc content with physical and chemical properties of soil in rice wheat cropping system in calcareous soils

\begin{tabular}{|c|c|c|c|c|c|c|c|c|c|c|c|c|c|}
\hline & $\begin{array}{l}\text { Cum- } \\
\text { Zn }\end{array}$ & OC & MWD & GMD & B.D & $\begin{array}{l}\text { Moist } \\
\text { cont }\end{array}$ & $\mathrm{pH}$ & EC & $\mathrm{N}$ & $\mathrm{P}_{2} \mathrm{O}_{5}$ & $\mathrm{~K}_{2} \mathrm{O}$ & $S$ & Yield \\
\hline $\begin{array}{l}\text { Cum- } \\
\text { Zn }\end{array}$ & 1 & & & & & & & & & & & & \\
\hline OC & $0.695^{* *}$ & 1 & & & & & & & & & & & \\
\hline MWD & $0.862^{* *}$ & $0.886^{* *}$ & 1 & & & & & & & & & & \\
\hline GMD & $0.718^{* *}$ & $0.968^{* *}$ & $0.905^{* *}$ & 1 & & & & & & & & & \\
\hline B.D & $-0.744^{* *}$ & $-0.848^{* *}$ & $-0.851^{* *}$ & $-0.817^{* *}$ & 1 & & & & & & & & \\
\hline $\begin{array}{l}\text { Moist } \\
\text { cont }\end{array}$ & $0.662^{*}$ & $0.670^{*}$ & $0.773^{* *}$ & $0.707^{* *}$ & $-0.864^{* *}$ & 1 & & & & & & & \\
\hline $\mathrm{pH}$ & $-0.585^{*}$ & $-\overline{0.249 \mathrm{NS}}$ & $-\overline{0.479 N S}$ & - $0.257 \mathrm{NS}$ & $0.491 \mathrm{NS}$ & $-0.649^{*}$ & 1 & & & & & & \\
\hline EC & $0.816^{* *}$ & $0.489 \mathrm{NS}$ & $0.617^{*}$ & $0.542 \mathrm{NS}$ & $-0.638^{*}$ & $0.713^{* *}$ & $-0.617^{*}$ & 1 & & & & & \\
\hline $\mathrm{N}$ & $0.742^{* *}$ & $0.896^{* *}$ & $0.882^{* *}$ & $0.847^{* *}$ & $-0.966^{* *}$ & $0.776^{* *}$ & $-0.378 \mathrm{NS}$ & $0.541 \mathrm{NS}$ & 1 & & & & \\
\hline P2O5 & $-0.970^{* *}$ & $-0.685^{* *}$ & $-0.832^{* *}$ & $-0.695^{* *}$ & $0.728^{* *}$ & $-0.650^{*}$ & $0.654^{*}$ & $-0.766^{* *}$ & $-0.728^{* *}$ & 1 & & & \\
\hline $\mathrm{K} 2 \mathrm{O}$ & $0.796^{* *}$ & $0.773^{* *}$ & $0.868^{* *}$ & $0.719^{* *}$ & $-0.927^{* *}$ & $0.798^{* *}$ & $-0.531 \mathrm{NS}$ & $0.603^{*}$ & $0.926^{* *}$ & $-0.802^{* *}$ & 1 & & \\
\hline S & $0.688^{* *}$ & $0.883^{* *}$ & $0.884^{* *}$ & $0.828^{* *}$ & $-0.901^{* *}$ & $0.809^{* *}$ & $-0.455 \mathrm{NS}$ & $0.582^{*}$ & $0.912^{* *}$ & $-0.676^{*}$ & $0.870^{* *}$ & 1 & \\
\hline Yield & $0.786^{* *}$ & $0.967^{* *}$ & $0.944^{* *}$ & $0.943^{* *}$ & $-0.928^{* *}$ & $0.794^{* *}$ & $-0.415 \mathrm{NS}$ & $0.605^{*}$ & $0.948^{* *}$ & $-0.768^{* *}$ & $0.888^{* *}$ & $0.925^{* *}$ & 1 \\
\hline
\end{tabular}

\section{CONCLUSION}

The cumulative yield of rice and wheat over six years was maximum in treatment $\mathrm{T}_{11}$, i.e. zinc applied @ $7.5 \mathrm{~kg} \mathrm{Zn} \mathrm{ha}^{-1}$ at every year $\left(1026.1 \mathrm{q} \mathrm{ha}^{-1}\right)$. It was at par with treatments $\mathrm{T}_{10}$ and $\mathrm{T}_{12}$, i.e. zinc applied @ 5.0 and $10 \mathrm{~kg} \mathrm{Zn} \mathrm{ha-1}$ every year

\section{REFERENCES}

Acquaye DK and Beringer H. 1989. Sulfur in Chinian soils: I. Status and distribution of different forms of sulfur in some typical profiles. Plant and Soil 113: 197-203.

Blake GR and Hartage KH. 1986. Bulk density, In: lute, A. (Ed.), Methods of Soil Analysis. Part 1. Physical and Mineralogical Methods, 2nd ed.: Agron. Monogr.9.ASA and SSSA, Madison, WI, pp.363-375.

Bower CA and Wilcox LV. 1965. Soluble salts. In: Black CA (ed) Methods of Soil Analysis. Part 2. American Society of Agronomy Inc, Madison, U.S.A, pp 933-951.

Chapman HD and Pratt PF. 1961. Methods of Analysis for Soils, Plants, and Waters. Riverside, CA: University of California.

Chepli WS. 1962. A compact rotary sieve and the importance of dry sieving in physical soil analysis. Soil Science Society of America Proceeding 26: 4-6.

Chesnin LA and Yien CH. 1950. Turbidimetric determination of available sulphates. Soil Science Society of America respectively and treatments $\mathrm{T}_{7}$ and $\mathrm{T}_{8}$, i.e. zinc applied @ 7.5 and $7.5 \mathrm{~kg} \mathrm{Zn} \mathrm{ha}{ }^{-1}$ in alternate year respectively. Thus, treatment $T_{7}$, i.e. application of zinc @ $7.5 \mathrm{~kg} \mathrm{Zn} \mathrm{ha}^{-1}$ in alternate year application was the best treatment with regards to yield of rice-wheat cropping (982.9 $\left.\mathrm{qha}^{-1}\right)$.

Proceeding 15: 149-151.

Jackson NL 1973. Soil Chemical Analysis. Prentice Hall of India, Pvt. Ltd., New Delhi.

Keram KS, Sharma BL and Savarkar SD. 2012. Impact of Zn application on yield, quality, nutrients uptake and soil fertility in a medium deep black soil (vertisol). International Journal of Science, Environment and Technology 1(5): 563-571.

Khadka D. 2016. The relationship between soil $\mathrm{pH}$ and micronutrients western Nepal. International journal of Agriculture Innovations and Research 3(1): 4-12.

Olsen SR, Culs CV, Wortanade FS and Dean LA. 1954. Estimation of available phosphorus by extraction with sodium bicarbonate. United States Department of Agriculture, 939: 19-23.

Piper CS. 1966. Soil Chemical Analysis. Asia Publishing House, Bombay, 408 pp.

Prasad R. 2005. Rice-wheat cropping systems. Advances in Agronomy 86, 285-339.

Singh AK and Bhatt BP. 2013. Effects of foliar application of zinc on 
growth and seed yield of late-sown lentil. Indian J. Agril. Sci. 83 (6): 622-626.

Singh AK, Meena MK, Bharati RC and Gade RM. 2013. Effect of sulphur and zinc management on yield, nutrient uptake, changes in soil fertility and economics in rice (Oryza sativa) lentil (Lens culinaris) cropping system.Indian J. Agril. Sci. 83 (3):344-348.

Singh RP and Mishra SK. 2012. Availability of macronutrients (N, P, K $\& S$ ) in the soils of chiraigaon block of district Varanasi (U.P) in relation to soil characteristics. Indian Journal of Soil Research 3(1): 97-100.
Subbiah BV and Asija GL. 1956. A rapid procedure for estimation of available nitrogen in soil. Current Science 25: 258-260.

Walkley A and Black CA. 1934. An examination of the Degtjareff methods for determination of soil organic matter and a proposed modification of the chromic acid titration method. Soil Science 37: 29-38.

Welch RM and Norvell WA. 1993. Growth and nutrient uptake by barley (Hordeum vulgare L. cv Herta): Studies using N-(2hydroxyethyl) ethylene dinitrolotri acetic acid-buffered nutrient solution technique. Plant Physiology 101: 627-631.

\section{Citation:}

Varalakshmi P, Nagarjuna P, Mohan Babu YN, Adi Lakshmi G, Kumari A and Singh SK.2021. Effect of zinc nutrition on yield of rice-wheat cropping system and soil properties. Journal of AgriSearch 8(1): 6-11 